\title{
ANALYSIS OF THE DEPENDENCE BETWEEN ENERGY DEMAND INDICATORS IN BUILDINGS BASED ON VARIANTS FOR IMPROVING ENERGY EFFICIENCY IN A SCHOOL BUILDING
}

\author{
Marta SKIBA ${ }^{1}$, Natalia RZESZOWSKA \\ University of Zielona Gora, Zielona Góra, Poland
}

\begin{abstract}
One of the five far-reaching goals of the European Union is climate change and sustainable energy use. The first step in the implementation of this task is to reduce energy demand in buildings to a minimum by 2021 , and in the case of public buildings by 2019 .

This article analyses the possibility of improving energy efficiency in public buildings, the relationship between particular indicators of the demand for usable energy (UE), final energy (FE) and primary energy (PE) in buildings and the impact of these indicators on the assessment of energy efficiency in public buildings, based on 5 variants of extensive thermal renovation of a school building.

The analysis of the abovementioned variants confirms that the thermal renovation of merely the outer envelope of the building is insufficient and requires the use of additional energy sources, for example RES. Moreover, each indicator of energy demand in the building plays a key role in assessing the energy efficiency of the building. For this reason it is important to analyze each of them individually, as well as the dependencies between them.

Keywords: energy efficiency, public buildings, school, RES, primary energy, final energy

\footnotetext{
${ }^{1}$ Corresponding author: University of Zielona Gora, Faculty of Civil Engineering, Architecture and Environmental Engineering, Szafrana st. 1, 65-516 Zielona Góra, Poland, e-mail: m.skiba@aiu.uz.zgora.pl.
} 


\section{INTRODUCTION}

A building is the result of an investment process that combines architectural, construction and installation solutions to create an object that affects the environment. As a result of an optimum use of technical solutions, we create a micro-environment inside the building to meet our needs and expectations. These solutions should not only focus on the comfort of the people using the building, but also on its high energy efficiency, coupled with the minimization of environmental impact. This statement fits in perfectly with the current EU energy and climate policy, whose main tasks are to improve energy efficiency, increase the share of renewable energy sources and reduce greenhouse gas emissions [12]. The plan to carry out these tasks has been divided into stages, and the stage currently under way is the strategy Europe 2020, covering the period up to 2020. The European Commission assumes that the actions taken should lead to the following results:

- In 2021 all new buildings should meet the standards for buildings with almost zero energy consumption and

- In 2019 new buildings used by public authorities and owned by them should meet the standards for buildings with almost zero energy consumption.

- In order to systematize energy efficiency issues in the Member States, the European Commission issued three main documents regulating the efficient use of energy in the construction industry:

- Directive 2010/31/EU of 19 May 2010 on the energy performance of buildings [3],

- Directive 2012/27/EU of 25 October 2012 on energy efficiency [4],

- Directive 2009/28/EC of 23 April 2009 on promoting the use of energy from renewable sources [5].

Although all three directives do not impose requirements that would be uniformly applicable in each EU country, they give an appropriate pace to the development of energy policy and indicate the path to follow in order to effectively implement the objectives set by the Commission. Poland, as a member state, is obliged to implement the directives into its domestic legislation. As a result, a number of changes have been made to the existing legislation and new legislative instruments have been enacted and implemented to meet the provisions of the EU Strategy [9].

The PE index $\left[\mathrm{kWh} / \mathrm{m}^{2}\right.$ per year] is used as the energy efficiency reference value, i.e. the total demand for non-renewable primary energy. The PE limit values are presented in Technical Conditions [10] in three stages, divided into periods: up to 2014, 2017 and 2019 (for public buildings). The energy classes of buildings have been abandoned in favour of a slider, which determines the value 
required for a new building and the value for the building to be assessed [11]. The indicator represented by the slider is primary energy.

Bearing in mind that the total energy use by the construction sector in the EU is $40 \%$ [3], 12\% [6] of which are used by public buildings, their role in the process of improving energy efficiency is significant. This important issue was taken into account while implementing the EU directives into Polish law by adopting the lowest PE indexes for this group of objects.

This article analyses the possibility of improving energy efficiency in public buildings, the relationship between particular indicators of the demand for usable energy (UE), final energy (FE) and primary energy (PE) in buildings and the impact of these indicators on the assessment of energy efficiency in public buildings based on 5 variants of extensive thermal renovation of the primary and secondary school building in Słubice.

\subsection{The state of research}

Literature presents many different approaches and methods to address the problem of improving energy efficiency in public utilities. In their article Dimitris Al. Katsaprakakis and George Zidianakis [7] discuss the modernization of 10 Greek schools in order to bring their energy class up to Category B or higher. Thanks to the use of energy from renewable energy sources in the buildings and replacing the existing equipment with more efficient lighting systems, e.g. LED light-bulbs, all buildings have reached that goal. This research further confirms the importance of the statement that renewable energy is a key issue in the case of extensive thermal renovation of public buildings. Karin Buvik and his team [1] presented the thermal renovation of a historic school building, which reduced its demand for primary energy by $67 \%$ and for final energy by $42 \%$. These results were achieved by the use of a heat pump with a ground exchanger, modernization of the ventilation system, replacement of the window frames, insulation of the basement walls and insulation of the attic and roof floor. Despite the fact that due to the historic facade of the building the external walls of the school were not insulated, the results of the renovation carried out were significant. On the basis of this research, it was proved that even historic buildings under the supervision of a historic preservation officer could reach high energy efficiency.

\section{BUILDING CHARACTERISTICS AND RESEARCH METHODOLOGY}

\subsection{School building in Słubice}

The building undergoing thermal renovation, housing the primary and secondary school, is located at 38 Wojska Polskiego Street in Słubice, the Lubusz 
Voivodship. The body of the object is built on the plan of several rectangles adjacent to each other and is located on the edge of its plot. It is a two-storey building with basements under its larger part. In the building there are classrooms, social and office facilities, a canteen, a common room, a gym and a company flat. The building was built using traditional full brick technology. The technical condition of the whole building has been assessed as satisfactory. The main entrance to the school is on the western side. Apart from the building, there are also sports fields, an athletics track and green areas in the plot.

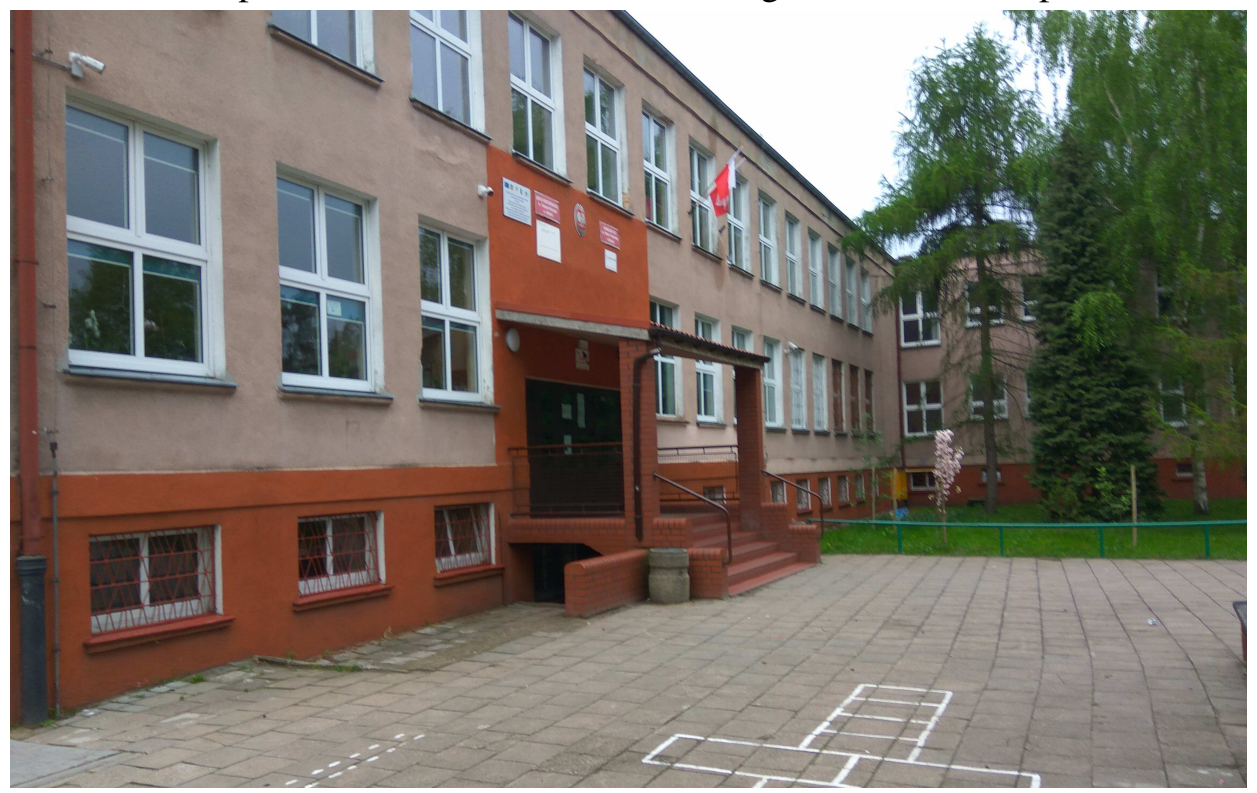

Phot. 1. Western elevation of the school building - main entrance. [N.Rzeszowska]

\subsection{Research method}

The paper presents 5 variants of extensive thermal renovation and shows methods to increase energy efficiency in public buildings. As a result of the extensive thermal renovation, the building meets the minimum requirements for new buildings according to the present forecast included Technical Conditions [10] for 2019. The UE, PE and FE values are estimated for each renovation variant of the building and its installations on the basis of the technical documentation of particular units and available literature on renovation of buildings and their installations. Each variant, in addition to the proposed improvements, also includes the renovation of the building envelope, presented as the base variant. The efficiency of installation systems is an approximate and declarative value. This value depends on a number of interrelated factors such as the quality of the building insulation and proper maintenance of equipment. 
Next, as a result of the analysis of indicators of the demand for usable energy (UE), final energy (FE) and primary energy (PE), the paper presents the relationships between these values and their impact on the energy efficiency of public buildings.

\section{RESEARCH}

\subsection{Variants of extensive thermal renovation}

BASE VARIANT - Modernization of the building envelope

- Insulation of the external walls above the ground $(\lambda=0.031 \mathrm{~W} / \mathrm{mK})$,

- Insulation of the external walls $(\lambda=0.029 \mathrm{~W} / \mathrm{mK})$,

- Insulation of the external walls of the basements $(\lambda=0.029 \mathrm{~W} / \mathrm{mK})$,

- Insulation of the flat roofs based on Ackermann's ceiling $(\lambda=0.037 \mathrm{~W} / \mathrm{mK})$,

- Replacement of the window and door frames in the whole building in order to achieve heat transfer coefficients in accordance with WT 2019.

VARIANT 1 - Modernization of the ventilation system

- Central ventilation unit with a nominal heat recovery output of $2500 \mathrm{~m}^{3} / \mathrm{h}$ equipped with an integrated water heater with a rated power of $1.65 \mathrm{~kW}$, installation of 5 units required to meet the air exchange demand of $11660 \mathrm{~m}^{3} / \mathrm{h}, 4$ wind turbines with vertical rotation axes $(\varnothing 6 \mathrm{~m})$ with a rated power of $10 \mathrm{~kW}$ equipped with $18 \mathrm{Ah}$ batteries and an inverter, which will supply power to the water heater of the central ventilation unit.

VARIANT 2 - Modernization of the usable hot water installation

- Installation of a brine/water type heat pump for usable hot water with a ground heat exchanger with a rated output of $39.8 \mathrm{~kW}$ and a COP coefficient of 6.9 , a power consumption of $5.8 \mathrm{~kW}$, a usable hot water tank with a capacity of 1000 litres equipped with an electric heater with a power output of $6 \mathrm{~kW}, 2$ sets of photovoltaic panels $(62 \times 240 \mathrm{~W})$ with an area of $100 \mathrm{~m}^{2}$ with a power output of $14.88 \mathrm{kWp}$, a set of photovoltaic panels $(52 \times 240 \mathrm{~W})$ with an area of $50 \mathrm{~m}^{2}$ with a power output of $12.48 \mathrm{kWp}$, a set of batteries for storing energy from the photovoltaic panels adjusted to the performance of the system.

VARIANT 3 - Modernization of the heating system

- Biomass boiler (wood) with a power output of $500 \mathrm{~kW}$, separation of the heating system of the company flat $\left(34 \mathrm{~m}^{2}\right)$, installation of the missing radiator thermostats.

VARIANT 4 - Modernization of the built-in lighting system

- lighting of the sports field and multi-purpose sports field: $10 \mathrm{x}$ hybrid LED lamps powered by photovoltaic panels and wind turbines, each with a power output of 48W, 
- $\quad$ Interior and exterior lighting of the school building: $2 \mathrm{x}$ vertical wind turbines $(\varnothing 1.8$ $\mathrm{m})$ with a rated power of $1 \mathrm{~kW}$, a set of photovoltaic panels $(62 \times 240 \mathrm{~W})$ with an area of $100 \mathrm{~m}^{2}$ with a power output of $14.88 \mathrm{kWp}$, a set of photovoltaic panels (52 $\mathrm{x} 240 \mathrm{~W}$ ) with an area of $50 \mathrm{~m}^{2}$ with a power output of $12.48 \mathrm{kWp}$, a set of batteries for storing energy from the photovoltaic panels and wind turbines adjusted to the performance of the system.

VARIANT 5 - Integrated project

- Use of improvements from all the abovementioned variants,

- Integration of all installations in the building by selecting a suitable control cabinet whose task will be to rationally manage the energy produced, the energy received from the mains and the energy consumed.

Table 1 . The annual demand for usable energy $\left[\mathrm{kWh} /\left(\mathrm{m}^{2} \mathrm{year}\right)\right]$

\begin{tabular}{|l|c|c|c|c|c|c|}
\hline & $\begin{array}{c}\text { Heating } \\
\text { and } \\
\text { ventilation }\end{array}$ & Cooling & $\begin{array}{c}\text { Hot } \\
\text { water }\end{array}$ & $\begin{array}{c}\text { Auxiliary } \\
\text { equipment }\end{array}$ & $\begin{array}{c}\text { Built-in } \\
\text { lighting }\end{array}$ & Total \\
\hline Base Variant & 56.45 & - & 15.23 & - & - & 71.68 \\
\hline Variant 1 & 39.52 & - & 15.23 & - & - & 54.75 \\
\hline Variant 2 & 56.45 & - & 15.23 & - & - & 71.68 \\
\hline Variant 3 & 56.45 & - & 15.23 & - & - & 71.68 \\
\hline Variant 4 & 56.45 & - & 15.23 & - & - & 71.68 \\
\hline Variant 5 & 39.52 & - & 15.23 & - & - & 54.75 \\
\hline
\end{tabular}

Table 2. The annual demand for final energy $\left[\mathrm{kWh} /\left(\mathrm{m}^{2}\right.\right.$ year $\left.)\right]$

\begin{tabular}{|l|c|c|c|c|c|c|}
\hline & $\begin{array}{c}\text { Heating } \\
\text { and } \\
\text { ventilation }\end{array}$ & Cooling & $\begin{array}{c}\text { Hot } \\
\text { water }\end{array}$ & $\begin{array}{c}\text { Auxiliary } \\
\text { equipment }\end{array}$ & $\begin{array}{c}\text { Built-in } \\
\text { lighting }\end{array}$ & Total \\
\hline Base Variant & 62.72 & - & 25.62 & 1.16 & 30.00 & 119.5 \\
\hline Variant 1 & 43.91 & - & 25.62 & 23.60 & 30.00 & 123.13 \\
\hline Variant 2 & 62.72 & - & 8.96 & 7.23 & 30.00 & 108.91 \\
\hline Variant 3 & 75.27 & - & 25.62 & 1.16 & 30.00 & 132.05 \\
\hline Variant 4 & 62.72 & - & 25.62 & 1.16 & 6.00 & 95.50 \\
\hline Variant 5 & 43.43 & - & 8.96 & 29.67 & 6.00 & 88.06 \\
\hline
\end{tabular}

Table 3 . The annual demand for primary energy $\left[\mathrm{kWh} /\left(\mathrm{m}^{2}\right.\right.$ year $\left.)\right]$

\begin{tabular}{|l|c|c|c|c|c|c|}
\hline & $\begin{array}{c}\text { Heating } \\
\text { and } \\
\text { ventilation }\end{array}$ & Cooling & $\begin{array}{c}\text { Hot } \\
\text { water }\end{array}$ & $\begin{array}{c}\text { Auxiliary } \\
\text { equipment }\end{array}$ & $\begin{array}{c}\text { Built-in } \\
\text { lighting }\end{array}$ & Total \\
\hline Base Variant & 68.99 & - & 46.68 & 3.47 & 90.00 & 209.14 \\
\hline Variant 1 & 48.30 & - & 46.68 & 3.48 & 90.00 & 188.46 \\
\hline Variant 2 & 68.99 & - & 0.00 & 3.47 & 90.00 & 162.46 \\
\hline Variant 3 & 15.05 & - & 46.68 & 3.47 & 90.00 & 155.20 \\
\hline Variant 4 & 68.99 & - & 46.68 & 3.47 & - & 119.14 \\
\hline Variant 5 & 8.69 & - & 0.00 & 3.47 & - & 12.16 \\
\hline
\end{tabular}




\subsection{Analysis of the variants and conclusions from the research}

The first four variants present the modernization of the building within a defined range, which comprises individual installations and building components, while Variant 5 presents an integrated project for the whole building. The thermal retrofitting of the building envelope has been adopted as the base variant, which causes the coefficient of heat transfer through the building façade to fall, and the efficiency of the modernized installation increases. As a result, the investment associated with the implementation of particular variants brings considerably greater economic and energetic benefits. Implementing only the base variant will not make it possible to meet any of the requirements specified in Technical Terms [10], so it is important to consider upgrading installation systems using, for example, additional energy carriers based on renewable energy sources (RES).

The objective of the abovementioned variants is to make the school building meet the current minimum requirements included Technical Terms [10]. The only variant that achieves this goal is Variant 5, which proposes an integrated project combining all other variants. The values of the individual energy indicators show the relationships between them. In the case of the other variants, the PE value is significantly higher than the UE or FE index, while In the case of Variant 5 the situation is reversed. The PE value directly depends on the energy source, so when RES equipment is used such as a biomass boiler, PV cells and a heat pump, the primary energy multiplier drops significantly (to 0.00). Usable energy remains on the same level as in Variant 1 (ventilation with heat recovery) because the heat losses and gains in the building do not change and the final energy value is slightly reduced because of the higher efficiency of the installation. Implementing Variant 5 results in very high investment costs, disproportionate with financial gains, since all in all it is final energy that is responsible for cost savings during the use of the building.

It is also worth noting the results obtained for Variant 4, which assumed the modernization of the inside lighting system. As a result of these measures, the $\mathrm{PE}$ index has been reduced to $119.14 \mathrm{kWh} / \mathrm{m}^{2}$ year, which is $224.23 \mathrm{kWh} / \mathrm{m}^{2}$ lower than the present value for the building and meets the standard for new buildings according to WT 2017 [10]. This project suggests replacing standard light bulbs with LED lighting, which makes the final energy demand for lighting in the building fall by $80 \%$. It should be emphasized that because of this modernization the value of the FE index is similar to the value presented for Variant 5 (the integrated project). The reduction of the EK index results in significant energy savings and in this way building operating are reduced. In order to reduce the value of the PE index, a set of photovoltaic cells and a small 
wind farm are used to satisfy the demand for energy in the school building, and self-sustaining hybrids are used for lighting the sports fields near the school. In this way, the demand for PE has been reduced by as much as $90 \mathrm{kWh} / \mathrm{m}^{2}$, which is $43 \%$ of the total demand for primary energy in the whole building. This has been achieved by using electric power from renewable energy sources whose primary energy factor is 0.00 , whereas for electric power obtained from fossil fuels the same indicator is 3.00 .

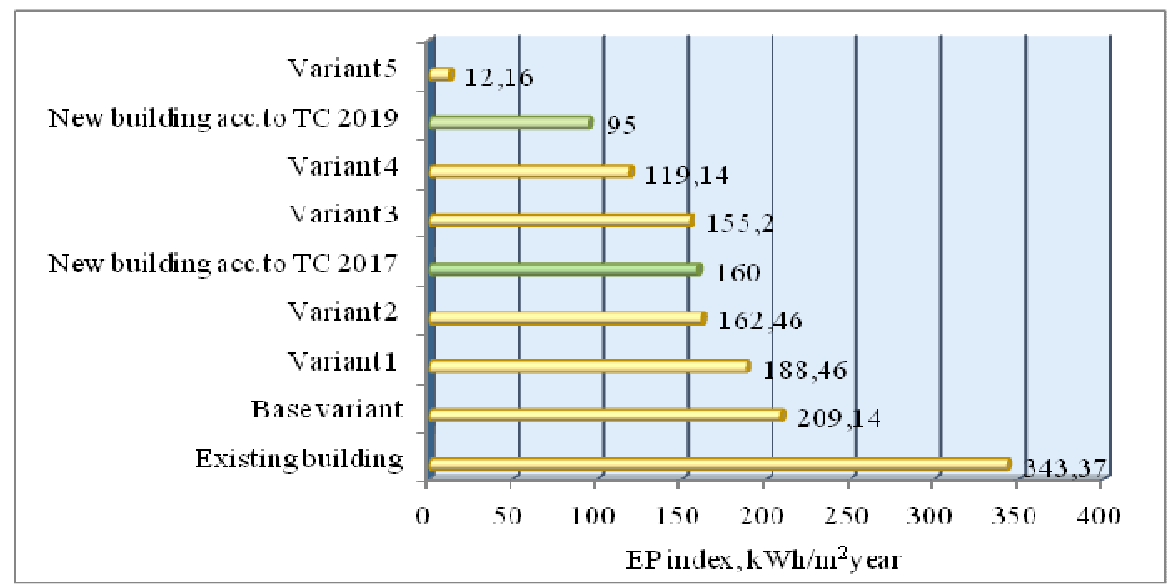

Fig. 1. Analysis of the variants considered on the basis of the primary energy demand index for heating, ventilation, hot water preparation and inside lighting of the school

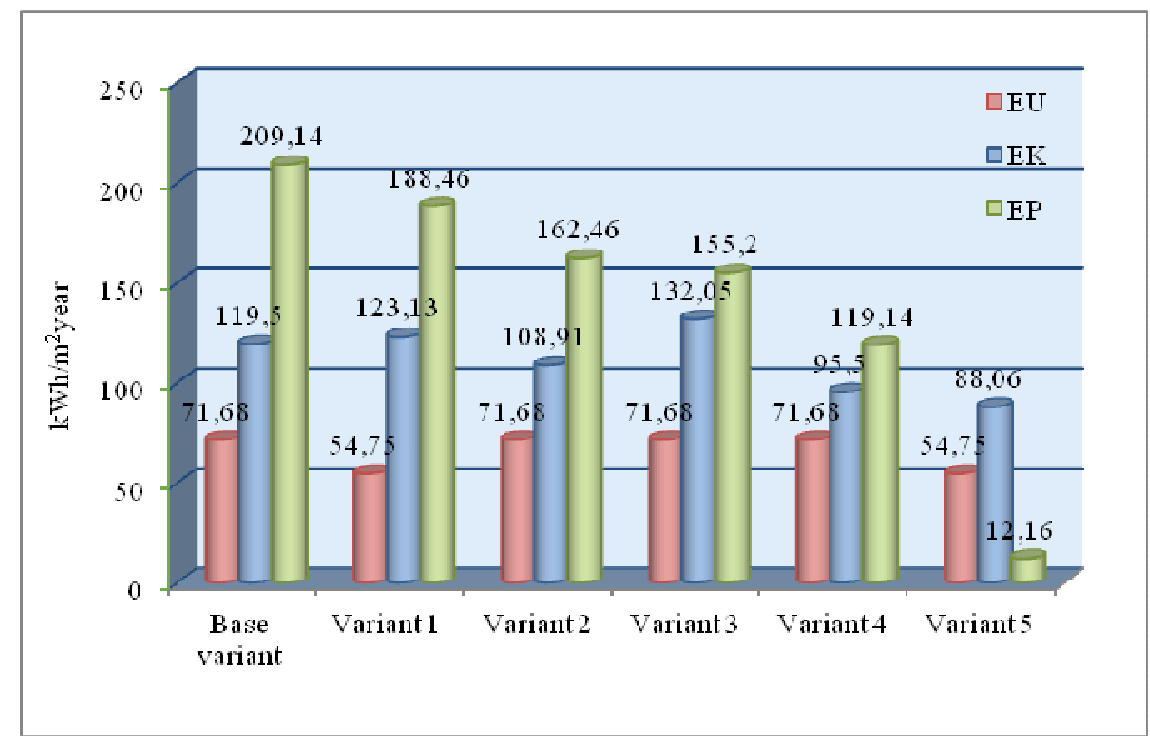

Fig. 2. EU, EK, EP values for individual variants 
This reduction in primary energy consumption directly contributes to the reduction of greenhouse gas emissions, which reduces the impact of the building on the environment.

\section{DISCUSSION AND CONCLUSIONS}

It results from the analysis of the abovementioned variants that the thermal renovation of the building envelope alone is not sufficient to bring the energy efficiency of the school up to the standard of Technical Conditions [10] after 2019. The only variant that satisfies these conditions is Variant 5, which proposes a project integrated with renewable energy.

Primary energy, analyzed in this case, determines the level of environmental impact that a building has and is determined on the basis of theoretically adopted coefficients. Assessing a building on the basis of this indicator is not reliable and sometimes misleads the buyer, the owner or the building manager. For example, a building with a really low PE index may be equipped with an obsolete heating system with a very low efficiency wood boiler. Because of the low biomass multiplier, the PE index is low but the energy demand of the building can be high as well as the operating costs. The FE index disregards the source of energy but takes into account the efficiency of the installations in the building and thus represents the actual energy demand of the building. In this way, the FE index has a direct impact on the operating costs of the building, which is very important for investors and future users. Knowledge of the relationship between $\mathrm{UE}, \mathrm{FE}$ and $\mathrm{PE}$ indexes is very important while implementing thermal retrofitting projects as well as designing buildings from scratch since they play a key role in assessing energy efficiency in the construction industry.

As a result of the analysis, it can be said without doubt that the extensive thermal renovation of the existing school building carried out to make it satisfy the present regulations for new buildings requires the invention of modern solutions and high quality workmanship. Only in this way is it possible to improve the energy efficiency of the building while maintaining optimum investment costs. Public buildings have a huge potential for reducing energy consumption. However, it is necessary to keep in mind the cost-effectiveness analysis of such an investment. Sometimes it may be less expensive to build three energy-efficient buildings from scratch than to retrofit just one. 


\section{REFERENCES}

1. Buvik K., Andersen G., Tangen S.: 2015. Energy upgrading of a historical school building in cold cli mate, Energy Procedia 78, 3342-3347.

2. Communication from the Commission to the European Parliament, the Council, the European Economic and Social Committee and the Committee of the Regions on a roadmap for moving to a competitive low carbon economy in 2050, $(\operatorname{COM}(2011) 112$ final, Brussels, 8.3.2011).

3. Directive of the European Parliment and of the Council of 2010/31/EU of 19 May 2010 on energy characteristics of buildings (Off. J. the EU L 153 of 19 June 2010, p. 13).

4. Directive of the European Parliment and of the Council of 2012/27/EU of 25 October 2012 on energy efficiency, amending Directives 2009/125/EC i 2010/30/E and repealing Direcyives 2004/8/EC i 2006/32/WE (Off. J. the EU L 315 of 14.11.2012, p. 1, as amended).

5. Directive of the European Parliment and of the Council of 2009/28/WE of 23 April 2009 on the promotion of the use of energy from renewable sources and amending and subsequently repealing Directives 2001/77/EC and 2003/30/EC (Off. J. the EU L 140 of 05.06.2009, p. 65).

6. Guide for improving the energy performance of buildings, The Ministry of Infrastructure and Building, Warszawa 2016

7. Katsaprakakis D. , Zidianakis G.: 2017. Upgrading Energy Efficiency For School Buildings In Greece, Procedia Enviromental Sciences, 38, 248-255.

8. Lis P.: 2009. Efektywność Energetyczna $w$ Systemach Budowlano Instalacyjnych. Materiaty dydaktyczne, Częstochowa, European Union.

9. Pyka S., Liszka S.: 2013. Efektywniej o efektywności, czyli jak najlepiej wdrożyć w Polsce Dyrektywę Parlamentu Europejskiego i Rady w sprawie efektywności energetycznej, Warszawa, Fundacja na rzecz Efektywnego Wykorzystania Energii.

10. The Regulation of the Minister of Infrastructure from April the 12th 2002 concerning technical conditions with which buildings and their location shall comply (Journal of Laws No. 75, item 690 as amended).

11. The Regulation of the Minister of Infrastructure from February the 27th 2015 on the methodology for determining the energy performance of the building or part of the building and energy performance certificates (Journal of Laws No. 0, item 376 as amended)

12. http://ec.europa.eu/europe2020/europe-2020-in-anutshell/targets/index_en.htm, September 2016.

13. https://ec.europa.eu/clima/policies/strategies/2050_en, February 2017. 


\section{ANALIZA ZALEŻNOŚCI MIĘDZY WSKAŹNIKAMI ZAPOTRZEBOWANIA NA ENERGIĘ W BUDYNKACH NA PODSTAWIE WARIANTÓW POPRAWY EFEKTYWNOŚCI ENERGETYCZNEJ BUDYNKU SZKOŁY}

\section{Streszczenie}

Jednym z pięciu dalekosiężnych celów Unii Europejskiej jest zmiana klimatu i zrównoważone wykorzystanie energii. Pierwszym etapem działań obejmujących realizację tego zadania jest ograniczenie zapotrzebowania na energię do minimum przez budynki do 2021, a w przypadku budynków użyteczności publicznej do 2019 r.

Prezentowany artykuł na przykładzie 5-ciu wariantów głębokiej termomodernizacji budynku szkoły, poddaje analizie możliwość podnoszenia efektywności energetycznej w obiektach użyteczności publicznej, zależność między poszczególnymi wskaźnikami zapotrzebowania na energię użytkową (EU), końcową (EK) i pierwotną (EP) w budynkach oraz wpływ tych wskaźników na ocenę efektywności energetycznej obiektów użyteczności publicznej.

Analiza przedstawionych wariantów potwierdza, iż wyłączna termomodernizacja osłony budynku jest niewystarczająca i wymaga zastosowania dodatkowych źródeł energii np. zastosowanie OZE. Ponadto, każdy wskaźnik zapotrzebowania na energię w budynku pełni kluczową rolę w ocenie efektywności energetycznej obiektu, dlatego istotnym jest analiza każdego z nich indywidualnie, jak i zależności między nimi.

Słowa kluczowe: efektywność energetyczna, budynki użyteczności publicznej, szkoła, OZE, energia pierwotna, energia końcowa

Editor received the manuscript: 06.09.2017 